\title{
Giant Multilocular Cystadenoma of the Prostate: A Rare Cause of Huge Cystic Pelvic Mass
}

\author{
Deniz Cebi Olgun, Bulent Onal ${ }^{1}$, Ismail Mihmanli, Fatih Kantarci, Haydar Durak ${ }^{2}$, Hale Demir ${ }^{2}$, \\ Bulent Cetinel $^{1}$ \\ Departments of Radiology, ${ }^{1}$ Urology, ${ }^{2}$ Pathology, Istanbul University Cerrahpasa Medical Faculty, Istanbul, Turkey
}

\begin{abstract}
Giant multilocular prostatic cystadenoma is a rare benign tumor that evolves from the prostate gland. Obstructive voiding symptoms occur in all reported cases. These lesions do not invade adjacent structures. Preoperative radiologic evaluation can define the benign nature of the lesion. Here we report a case of large cystic lesions identified by magnetic resonance imaging and sonographic findings that caused an extensive mass effect in the pelvis. When retrovesical, huge cystic lesions fill the pelvis completely in young men, with high levels of serum prostate-specific antigen, giant multilocular prostatic cystadenoma should be considered as a differential diagnosis. To our knowledge, this is the youngest case of prostatic cystadenoma reported in the literature.
\end{abstract}

\section{Key Words: Cystadenoma; Prostate; Prostatic neoplasms}

This is an Open Access article distributed under the terms of the Creative Commons Attribution Non-Commercial License (http://creativecommons.org/licenses/by-nc/3.0) which permits unrestricted non-commercial use, distribution, and reproduction in any medium, provided the original work is properly cited.

\author{
Article History: \\ received 17 May, 2011 \\ accepted 13 June, 2011 \\ Corresponding Author: \\ Bulent Onal \\ Department of Urology, Istanbul \\ University Cerrahpasa Medical \\ Faculty, Kocamustafapasa, 34303 \\ Istanbul, Turkey \\ TEL: +90-212-4142917 \\ FAX: $+90-212-4143167$ \\ E-mail: bulonal@yahoo.com
}

Giant multilocular prostatic cystadenoma is a rare benign tumor of the prostate gland [1,2]. Prostatic cystadenoma is usually characterized by large multilocular cysts that are located between the rectum and the bladder. The clinical presentation includes obstructive voiding symptoms, such as poor stream, intermittency, straining, and a sensation of incomplete emptying, and also defecation symptoms that result from the compression of the lower gastrointestinal system [1-10]. These lesions do not invade adjacent structures or show any malignant characteristics. Imaging modalities can be used to describe the cystic nature of the lesions and show their relationship to adjacent organs. Here we report the youngest known patient presenting with large cystic lesions that caused an extensive mass effect in the pelvis.

\section{CASE REPORT}

A 23-year-old man presented with a 7-month history of obstructive voiding symptoms and reported recently having difficulty in defecation. His obstructive voiding symptoms were characterized by a weak urinary stream with intermittent flow, straining, and a sensation of incomplete voiding. The results of the digital rectal examination showed an enlarged prostate gland. The results of laboratory tests were normal except for an elevated serum prostate-specific antigen (PSA) level of $20.2 \mathrm{ng} / \mathrm{ml}$ (range, 0 to $4 \mathrm{ng} / \mathrm{ml}$ ). Transabdominal and transrectal ultrasound examination was performed with an Acuson S2000 (Siemens Medical Solutions Mountain View, CA, USA). The scans revealed a $12 \times 17 \times 12 \mathrm{~cm}$ anechoic cystic mass with multiple thin, echogenic internal septations and moving echogenic debris and multiple cysts in a cyst appearance (Fig. 1). The prostate gland was compressed by the mass in the rectovesical space. Either prostate or seminal vesicles could be visualized.

The patient underwent further assessment with Signa EXCITE 1.5T (GE Medical Systems Waukesha, WI, USA) magnetic resonance imaging (MRI). The MRI showed a multiseptated, huge cystic lesion that filled the pelvis completely. T2 and T1 weighted images showed different intensity of the cysts according to fat, mucinous, or blood contents. The bladder was displaced in an anterior and left lateral superior position and was compressed by this mass; however, a plane of interface was visualized between the mass and the bladder. The rectum was not compressed by the mass (Fig. 2). Sonographically guided transrectal fineneedle aspiration was performed, and 1,140 $\mathrm{ml}$ of fluid was 

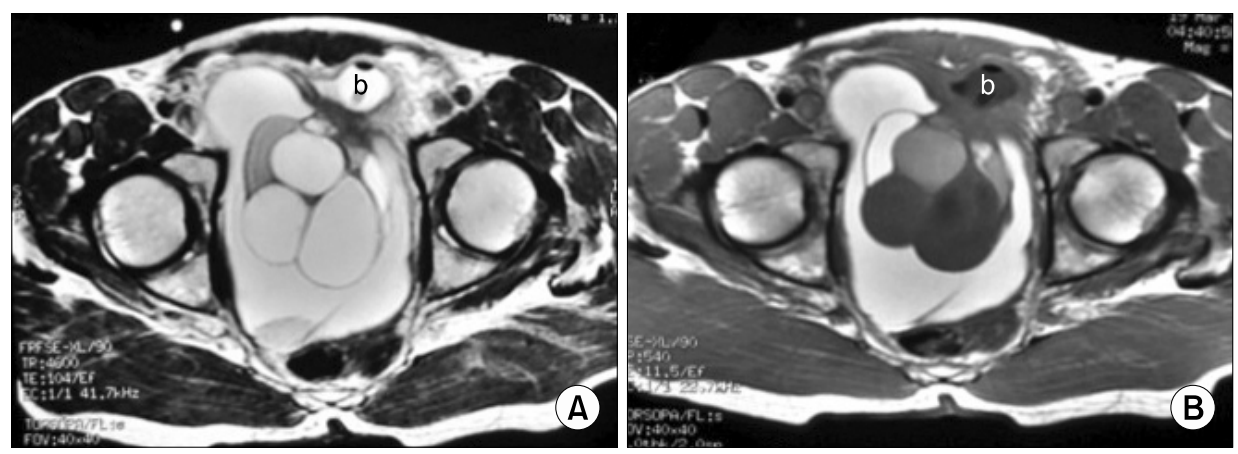

FiG. 1. Transabdominal sonography images in sagittal (A) and transverse (B) planes showing a well-defined, encapsulated, anechoic huge cystic mass with multiple thin, echogenic internal septations presenting in a cyst appearance.
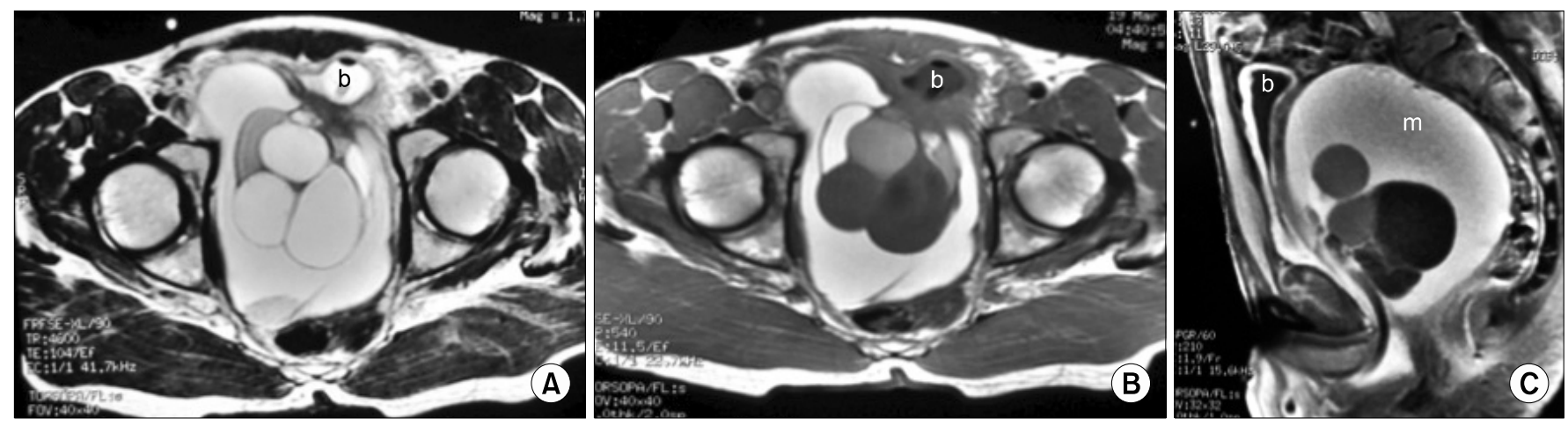

FiG. 2. Preoperative magnetic resonance imaging (MRI) images: (A) axial T2-weighted image showing a multiloculated cystic mass displacing the bladder catheter balloon (b) within the bladder lumen in a left anterior position, (B) the same section in an axial T1-weighted image displaying a different intensity in the multiloculated cystic mass, and (C) the sagittal fat sat T1-weighted image showing an apparent mucinous component of the lesion (m).

drained. The results of laboratory examinations were normal except for a total protein level of $8.95 \mathrm{~g} / \mathrm{dl}$ (reference range, $<2.0 \mathrm{~g} / \mathrm{dl})$. Cytologic examination of the fluid showed only red blood cells and histiocytes with groups of benign epithelial cells and no evidence of malignancy. The patient then underwent laparotomy. Because complete excision was not surgically feasible, after examination of initial frozen sections confirmed the mass as a benign lesion, debulking of the mass was performed. The gross pathologic specimen was a $7 \times 5 \times 2.5 \mathrm{~cm}$ solid mass containing multiple small cysts and a $9 \times 9 \times 0.2 \mathrm{~cm}$ cystic component. The surgical margin status of the cystadenoma was positive. Cyst contents include serous and mucinous fluids. Histologically, the tumor was composed of variously sized, dilated glandular structures lined by prostatic epithelia. Microscopically, the cysts were lined by flat to cuboid epithelia with pale cytoplasm and basally located nuclei without nucleoli. No atypical features or mitosis was noted in either the glandular or the stromal components of the mass. The prostatic origin of the epithelia was confirmed by positive immunohistochemical staining for PSA (Fig. 3). Final histology reported a multilocular prostatic cystadenoma. The patient was under follow-up for 18 months and there was no evidence of recurrence.

\section{DISCUSSION}

Giant multilocular prostatic cystadenoma is a rare, benign neoplasm that originates in the prostate gland, as shown in Table 1 [1-10]. The clinical presentation in all patients is similar to benign prostatic hyperplasia and includes obstructive voiding symptoms and acute urinary retention with or without a palpable abdominal mass $[1-6,10]$. In the literature, patients' ages vary, ranging from 28 to 80 years old (Table 1) [1-10]. Enlargement of the prostate is typically seen by digital rectal examination. Before the development of imaging techniques, patients with these clinical symptoms could be falsely diagnosed as having giant benign prostatic hyperplasia. Computed tomography (CT) and in particular MRI can provide information on a large multicystic process originating from the prostate, but a clear origin cannot always be determined. It is difficult to diagnose, despite extensive radiological assessment (transabdominal and transrectal ultrasound, CT, and MRI of the pelvis). However, imaging studies are useful for determining the extent and invasiveness of the lesion.

Differential diagnosis for cystic lesions of the prostate or surrounding structures includes simple prostatic cyst, phyllodes variant of a typical prostatic hyperplasia, sarcoma of the prostate, prostatic leiomyoma, echinococcal cysts of the prostate, müllerian duct cysts, cystic dilatation of the 


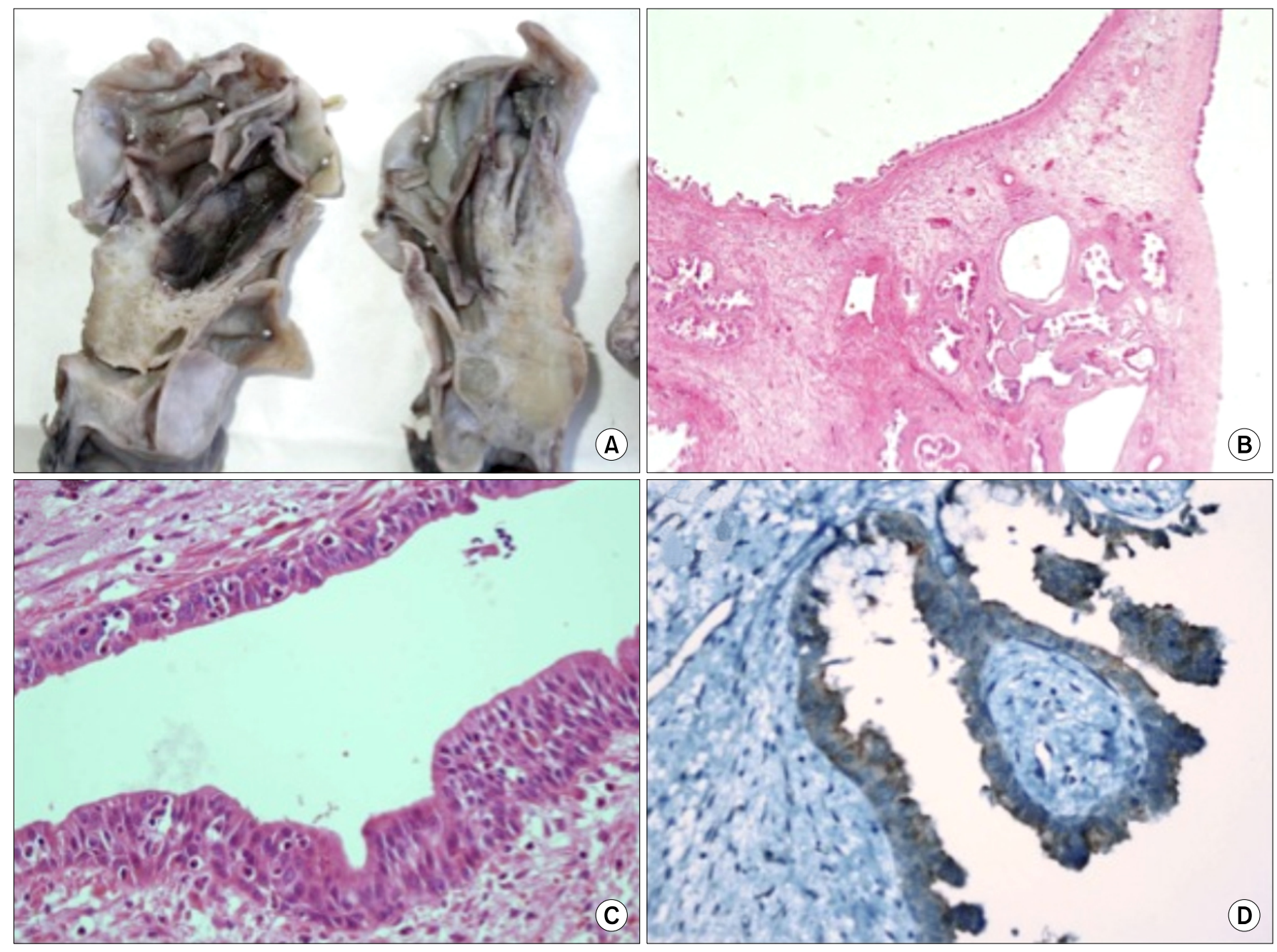

FiG. 3. Histopathological findings: (A) Macroscopic aspect of the giant multilocular cystadenoma of the prostate. (B) The lesion shows well-developed, dilated prostate glands (H\&E, x40). (C) The dilated cysts are lined by cuboidal to low-columnar epithelial cells with basally located nuclei (H\&E, x40). (D) Immunoperoxidase staining with the prostate-specific antigen stain ( $\mathrm{x} 400)$.

utricle, diverticulum of the ejaculatory duct or ampulla of the vas deferens, seminal vesicle cysts, pelvic mesothelioma, multilocular peritoneal inclusion cyst, teratoma, lymphangioma, and prostatic cystic carcinoma $[7,8]$. Prostatic cystadenomas do not invade adjacent organs; they produce a mass effect on them. Rusch et al. [8] reported that radiographic evidence of invasion of the adjacent structures primarily excludes the possibility of a giant multilocular prostatic cystadenoma. PSA staining can disclose the prostatic origin of this lesion [5-7]. Only by histology is a clear and definitive diagnosis possible. Giant multilocular prostatic cystadenoma is characterized by typical prostate gland cysts lined with double layers of columnar and cuboid cells with basally located nuclei and pale cytoplasm and epithelial cells, positive PSA staining, and no signs of malignancy [1-10]. In contrast, the cells lining the cystadenocarcinoma show nuclear stratification, papillary proliferations, and roman arch structures. The growth pattern of the cystadenocarcinoma is invasive, with destruc- tion of prostatic parenchyma and aggressive invasion into the periprostatic adipose tissue. Allen et al. [9] first described high-grade prostatic intraepithelial neoplasia within a multilocular prostatic cystadenoma.

Treatment for giant multilocular prostatic cystadenoma is complete surgical excision, which provides a pathological diagnosis as well as a cure. Despite their benign nature, if these tumors are partially excised, they can regenerate and the same symptoms can recur. Recurrences have been treated by surgery, such as mass excision [8] and pelvic exenteration [2]; more recently, treatment with the gonadotropin-releasing hormone agonist (leuprolide acetate) [10] has been performed. We did not consider prostatectomy as a treatment option for our patient both because he was too young (not married and no children) and we confirmed the benign nature of the mass before surgery. In addition, we did not think to delay the surgery because he had very severe obstructive voiding and defecation symptoms. In conclusion, when a retrovesical, huge cystic lesion fills the pel- 
TABLE 1. Comparison of clinical findings, mass volume, PSA level, treatment, and follow-up between 1990 and the present case (2011)

\begin{tabular}{|c|c|c|c|c|c|c|c|c|c|}
\hline & Year & $\begin{array}{l}\text { Patient } \\
\text { age }(\mathrm{yr})\end{array}$ & Clinical symptoms & $\begin{array}{l}\text { PSA } \\
(\mathrm{ng} / \mathrm{ml})\end{array}$ & Size $(\mathrm{cm})$ & $\begin{array}{l}\text { Volume } \\
\text { (g) }\end{array}$ & $\begin{array}{l}\text { Radiologic } \\
\text { findings }\end{array}$ & Treatment & Follow-up \\
\hline $\begin{array}{l}\text { Watanabe et } \\
\text { al. [1] }\end{array}$ & 1990 & 80 & Urinary retention & - & $11 \times 8 \times 7$ & 660 & - & $\begin{array}{l}\text { Anterior pelvic } \\
\text { exenteration }\end{array}$ & - \\
\hline \multirow[t]{2}{*}{ Maluf et al. [2] } & \multirow[t]{2}{*}{1991} & 28 & $\begin{array}{l}\text { Acute urinary } \\
\text { retention }\end{array}$ & - & $19 \times 8 \times 7$ & 600 & - & Surgical excion & $\begin{array}{l}4 \text { months, no } \\
\text { recurrence }\end{array}$ \\
\hline & & 38 & $\begin{array}{l}\text { Difficulty in } \\
\text { micturition dysuria }\end{array}$ & - & $45 \times 35 \times 13$ & 6,500 & - & $\begin{array}{l}\text { Exenteration } \\
\text { and pelvic } \\
\text { irradiation }\end{array}$ & $\begin{array}{l}2 \text { years, local } \\
\text { recurrence }\end{array}$ \\
\hline Lim et al. [3] & 1993 & 64 & $\begin{array}{l}\text { Lower abdominal } \\
\text { pain, obstruction } \\
\text { voiding symptoms }\end{array}$ & - & $17 \times 13 x 7$ & - & Fluid-filled mass & Enbloc excision & - \\
\hline Levy et al. [4] & 1993 & 56 & $\begin{array}{l}\text { Urinary } \\
\text { retentionpolyuria, } \\
\text { obstructivevoiding } \\
\text { disfunction }\end{array}$ & - & $13 \times 10 \times 7$ & - & $\begin{array}{l}\text { Multiseptate } \\
\text { thickened walls }\end{array}$ & Mass resection & $\begin{array}{l}8 \text { years, no } \\
\text { recurrence }\end{array}$ \\
\hline \multirow[t]{2}{*}{$\begin{array}{l}\text { Kirsch et al. } \\
{[5]}\end{array}$} & 1996 & 65 & $\begin{array}{l}\text { Obstructive voiding, } \\
\text { hematuria }\end{array}$ & 30.2 & $15 \times 12.5 \times 3$ & 130 & $\begin{array}{l}\text { Heterogenous/ } \\
\text { multiloculated } \\
\text { mass }\end{array}$ & Enucleation & $\begin{array}{l}1 \text { year no } \\
\text { recurrence }\end{array}$ \\
\hline & 1998 & 43 & Hematuria & 68.2 & $8 \times 7.5 \times 6$ & 180 & Cystic-solid mass & Mass resection & No recurrence \\
\hline \multirow{3}{*}{$\begin{array}{l}\text { Seong et al. [6] } \\
\text { Matsumoto et } \\
\text { al. [7] } \\
\text { Rusch et al. [8] }\end{array}$} & 2002 & 35 & Gross hematuria & 14.4 & $9 \times 8 \times 6$ & - & $\begin{array}{l}\text { Multilocular } \\
\text { mass }\end{array}$ & $\begin{array}{l}\text { Cystoprosta- } \\
\text { tectomy }\end{array}$ & $\begin{array}{l}2 \text { years no } \\
\text { recurrence }\end{array}$ \\
\hline & 2002 & 30 & $\begin{array}{l}\text { Urinary } \\
\text { retentionlower } \\
\text { urinary tract } \\
\text { symptoms }\end{array}$ & 2 & 15 & - & Multilocular cyst & Mass resection & $\begin{array}{l}18 \text { months, no } \\
\text { recurrence }\end{array}$ \\
\hline & & 41 & $\begin{array}{l}\text { Acute urinary } \\
\text { retention }\end{array}$ & - & 15 & - & $\begin{array}{l}\text { Multilocular } \\
\text { cysticmass }\end{array}$ & Excision & - \\
\hline Allen et al. [9] & 2003 & 52 & $\begin{array}{l}\text { Lower urinary tract } \\
\text { symptoms, gross } \\
\text { hematuria }\end{array}$ & 3 & $14 x 10 x 1$ & 140 & $\begin{array}{l}\text { Multiloculated } \\
\text { cystic pelvic } \\
\text { mass }\end{array}$ & Resection & - \\
\hline $\begin{array}{l}\text { Datta et al. } \\
{[10]}\end{array}$ & 2003 & 71 & Urinary retention & 40 & $12 x \ldots$ & - & Cystic mass & $\begin{array}{l}\text { Excision, } \\
\text { cystoprosta- } \\
\text { tectomy and } \\
\text { lupron }\end{array}$ & $\begin{array}{l}11 \text { years } \\
\text { recurrencex } 2\end{array}$ \\
\hline Present case & 2011 & 23 & $\begin{array}{l}\text { Obstructive voiding } \\
\text { symptoms, } \\
\text { difficulty in } \\
\text { defecation }\end{array}$ & 20.2 & $12 \times 17 \times 12$ & - & $\begin{array}{l}\text { Multiseptate } \\
\text { huge cystic } \\
\text { lesion }\end{array}$ & Excision & $\begin{array}{l}18 \text { months no } \\
\text { recurrence }\end{array}$ \\
\hline
\end{tabular}

PSA, prostate-specific antigen.

vis completely in young men, with high levels of serum PSA, giant multilocular prostatic cystadenoma should be considered as a differential diagnosis.

\section{CONFLICTS OF INTEREST}

The authors have nothing to disclose.

\section{REFERENCES}

1. Watanabe J, Konishi T, Takeuchi H, Tomoyoshi T. A case of giant prostatic cystadenoma. Hinyokika Kiyo 1990;36:1077-9.

2. Maluf HM, King ME, DeLuca FR, Navarro J, Talerman A, Young RH. Giant multilocular prostatic cystadenoma: a distinctive lesion of the retroperitoneum in men. A report of two cases. Am J Surg Pathol 1991;15:131-5.
3. Lim DJ, Hayden RT, Murad T, Nemcek AA Jr, Dalton DP. Multilocular prostatic cystadenoma presenting as a large complex pelvic cystic mass. J Urol 1993;149:856-9.

4. Levy DA, Gogate PA, Hampel N. Giant multilocular prostatic cystadenoma: a rare clinical entity and review of the literature. J Urol 1993;150:1920-2.

5. Kirsch AJ, Newhouse J, Hibshoosh H, O'Toole K, Ritter J, Benson MC. Giant multilocular cystadenoma of the prostate. Urology 1996;48:303-5.

6. Seong BM, Cheon J, Lee JG, Kim JJ, Chae YS. A case of multilocular prostatic cystadenoma. J Korean Med Sci 1998;13:554-8.

7. Matsumoto K, Egawa S, Iwabuchi K, Baba S. Prostatic cystadenoma presenting as a large multilocular mass. Int J Urol 2002;9:410-2.

8. Rusch D, Moinzadeh A, Hamawy K, Larsen C. Giant multilocular cystadenoma of the prostate. AJR Am J Roentgenol 2002;179: 
1477-9.

9. Allen EA, Brinker DA, Coppola D, Diaz JI, Epstein JI. Multilocular prostatic cystadenoma with high-grade prostatic intraepithelial neoplasia. Urology 2003;61:644.
10. Datta MW, Hosenpud J, Osipov V, Young RH. Giant multilocular cystadenoma of the prostate responsive to $\mathrm{GnRH}$ antagonists. Urology 2003;61:225. 